This paper is published as:

McCabe, BY, Loughlin, C, Munteanu, R, Tucker, S and Lam, A, 2008, "Individual Safety and health outcomes in the construction industry", Canadian Journal of Civil Engineering, 35:14551467

\title{
INDIVIDUAL SAFETY AND HEALTH OUTCOMES IN THE CONSTRUCTION INDUSTRY
}

Brenda McCabe ${ }^{1}$, Catherine Loughlin ${ }^{2}$, Ramona Munteanu ${ }^{3}$, Sean Tucker ${ }^{4}$, and Andrew Lam ${ }^{5}$

\begin{abstract}
Between 2004 and 2006, 911 self-administered questionnaires were collected from 84 non-residential Ontario construction sites. Each questionnaire contained 105 questions and took approximately 15 minutes to complete. This paper presents one study from that research project that seeks to understand the relationship among worker demographics, worker safety attitudes, and worker health and safety outcomes (e.g., worker well-being and accidents). The participants had an average age of 38.3 years with 15.1 years of experience in the industry. Short job tenure, age, experience, and job position were highly related to safety outcomes. Apprentices experienced more accidents, while supervisors reported more workrelated psychological symptoms. Among the situational factors, higher work pressure, high interpersonal conflict, and low quality leadership were most strongly associated with workrelated health outcomes and accidents. Regression models were developed with a maximum adjusted coefficient of determination of 0.28 . A graphical means of modeling the data was demonstrated in the form of a Bayesian belief network.
\end{abstract}

KEY WORDS: Attitudes, safety, construction, Bayesian network, regression

\section{INTRODUCTION}

The construction industry in Ontario, Canada is a world leader in both safety standards and safety results (CSAO 2004a). This is largely attributed to the support offered by government boards and employer associations which actively involve themselves in improving safety.

Although a downward trend in construction fatalities is evident from 1966-2004 (

Figure 1), a spike in 2003 was a significant concern to the government, employer associations, unions, and frontline workers. There were 30 deaths reported in the Ontario construction sector in 2003, up 58\% from 2002 (CSAO 2004a). Because it is commonly accepted that deaths represent the tip of the iceberg in terms of workplace safety, concern is justifiable.

\footnotetext{
${ }^{1}$ Associate Professor, Department of Civil Engineering, University of Toronto, Canada

2 Canada Research Chair, Sobey School of Business, Saint Mary's University, Canada

3 Master's student, Department of Civil Engineering, University of Toronto, Canada

4 PhD Candidate, School of Business, Queens University, Canada

${ }^{5}$ Research Assistant, Department of Civil Engineering, University of Toronto, Canada
} 
Bird (1974) proposed that for each major injury (including both fatalities and critical injuries) there may be as many as 600 near-misses (Figure 2). Data in the Ontario construction industry would seem to support this proposition; Among the 396,000 workers in this industry (CSAO 2005 ) there were 20 deaths. That same year, the Workplace Safety Insurance Board (WSIB) of Ontario (2005a) reported that there were almost 5,600 lost-time injuries. This represents a significant cost to workers, organizations, and society and suggests that it may be time to begin paying closer attention to 'micro accidents' or 'near misses' that are likely to lead to injury and/or death in this industry.

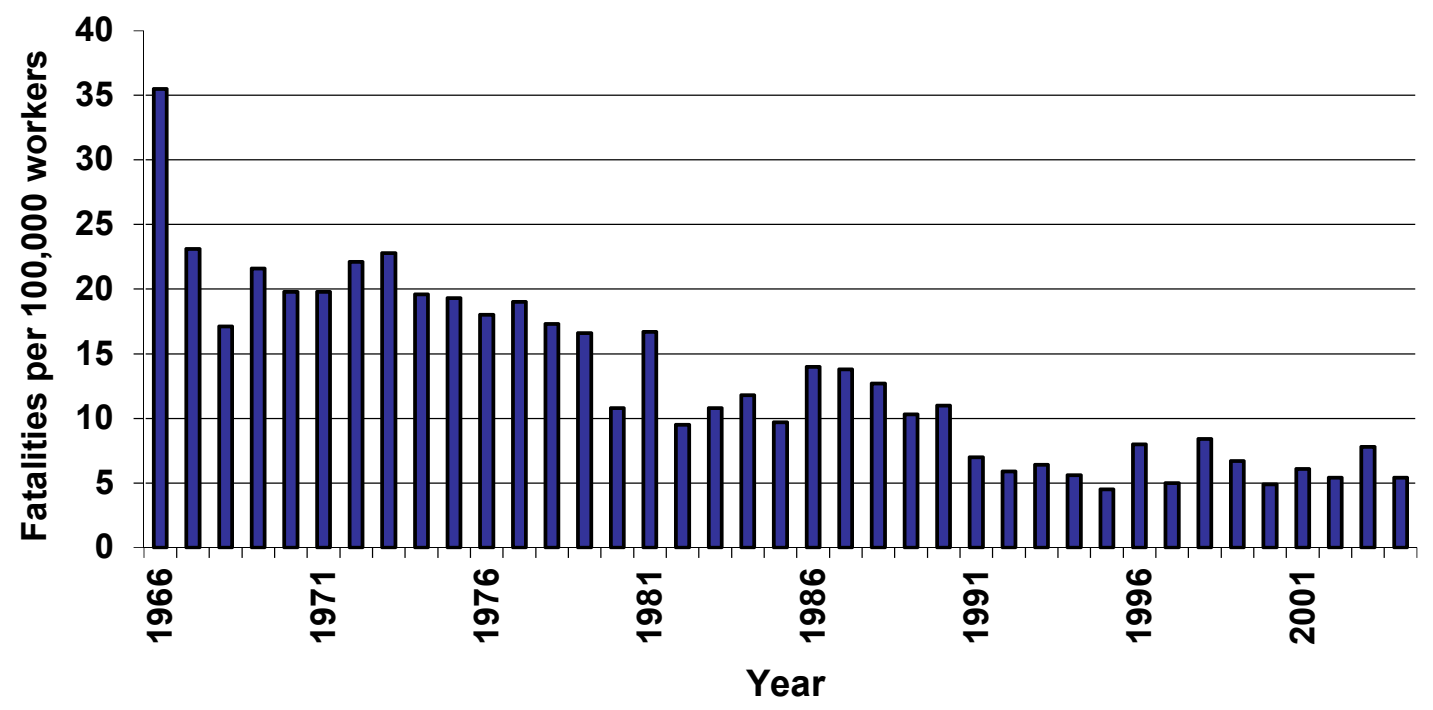

Figure 1: Fatalities per 100,000 workers (adapted from CSAO 2004a)

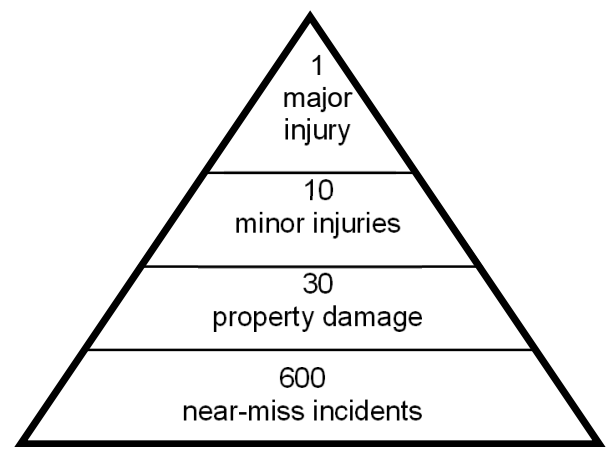

Figure 2: Incident pyramid

This paper presents one study from a major research project that seeks to understand some of the individual (e.g., personality) and situational (e.g., quality of supervision) correlates of three work-related health and safety outcomes in the construction industry. These outcomes include the prevalence of work-related accidents, psychological and physical symptoms. A unique contribution of this study is that we use two distinct approaches - multiple linear regression models and a Bayesian belief network - to analyze our data and explore these relationships. We also contribute to the literature by adding a data point to safety research in the construction industry, by investigating incidents likely to lead to injury in addition to accident outcomes. 


\section{LITERATURE REVIEW}

Research has shown that occupational health and safety outcomes are related to both individual and situational factors (Barling \& Frone 2004). We discuss each category separately beginning with individual factors. Table 1 summarizes the relationships between the individual and situational factors, and the three safety outcomes (i.e., prevalence of work-related accidents, psychological symptoms, and physical symptoms). Because so few of these relationships have been studied in the construction industry, we make no prediction about the relative strength of each of these factors; instead we treat strength as an empirical question.

\section{Individual Factors}

The current study analyzes four individual predictors of accidents and well-being: age, conscientiousness, safety consciousness, and fatalism. Several studies have shown that younger workers are more likely to be injured on the job than older workers (Loughlin \& Frone 2004; Salminen 2004), and nationally representative studies suggest that psychological health generally improves with age (Korten \& Henderson 2000). Research has shown that two personality variables, conscientiousness - defined as the degree that someone is careful and mindful when doing tasks - and safety-specific conscientiousness, are negatively correlated with both workplace injuries (Clarke \& Robertson 2005; Kelloway et al. 2006) and physical health (Grant \& Langan-Fox 2007), but not related to psychological health (Miller et al. 1999). The relationship between fatalism (defined as the feeling that external forces have more influence over ones own safety) and accidents remains unclear (Harrell 1995), however studies suggest that fatalism is negatively related to psychological well-being Daniels \& Guppy 1997; (Danna \& Griffin 1999).

\section{Situational Factors}

Safety research has moved from a focus on individual workers toward workplace factors, with a growing emphasis on systems approaches (considering the influence of work groups on individual safety). Cooper (1998) defined work attitudes as psychological constructs that describe how people consistently think, feel, and behave toward a particular object. Attitudes are socially constructed because people tend to internalize the views and opinions of persons close to them, such as their coworkers or supervisors.

Numerous scales measure safety climate (Zohar 1980; Shannon et al. 1997; Williamson 1997; Glendon \& Stanton 2000). No single measure of safety climate is consistent across industries (Coyle et al. 1995), although several underlying themes have been identified, including management and supervision, safety system, risk perception, work pressure, attitudes regarding skill level, qualifications and job knowledge (Flin et al. 2000; Vredenburgh 2002).

Only two papers pertaining to safety climate in the construction industry are widely recognized (Dedobbeleer \& Beland 1991; Glendon \& Litherland 2001). Factors influencing safety climate are thought to be dependent on location (Gadd \& Collins 2002). This may be one reason why there are so few studies pertaining to the construction industry, as the "workplace" is continuously changing. Perhaps most importantly, the temporary nature of the physical workplace may not allow a safety climate to be established. This study attempts to examine safety climate in this unique, sometimes dangerous, work environment.

Safety climate, defined as the shared perceptions of safety practices and policies among coworkers, supervisors, and management, has been the focus of much research in the past decade (Clarke 2006). While some studies find that safety climate is associated with lower injury rates, a recent meta-analytic study suggested that safety climate in general has no effect on accidents and injuries (Clarke 2006). In this study, we consider the components contributing to workplace safety climate separately (e.g., safety programs, co-workers, supervisors, 
management). In terms of psychological health, meta-analytic evidence suggests that workers in supportive work climates report higher psychological health (Carr et al. 2003). Relatedly, studies show that high social support is related to higher psychological well-being (Lee \& Ashforth 1996).

The relationship between the quality of supervision and accidents is fairly consistent, with most studies showing a negative relationship between high quality supervisory leadership, and accidents and injuries (Hinze \& Gordon 1979; Hinze 1987; Barling et al. 2002; Hofmann \& Morgeson 2004; Kelloway et al. 2006). Also, evidence shows that supportive and encouraging supervision (i.e., high quality leadership) is associated with higher levels of employee wellbeing (Hinze 1981; Sosik \& Godshalk 2000; Barling et al. 2005).

In terms of unionization, studies have shown that when workers experience unsafe work they are more likely to join a trade union (Barling et al. 2003). With respect to psychological wellbeing, the evidence is inconclusive; one study found unionized workers experienced more worry and stress on the job than non-union workers (Baugher \& Roberts 1999). The literature suggests that union members tend to have a more realistic view of their job and consequently show less satisfaction than their non-union counterparts (Bender \& Sloane 1998). This does not necessarily mean that union members are less satisfied with their supervision, leadership or the job itself, but that they tend to be more aware of, and have a means to address important issues. Baugher (2004) found that unions help workers cope with workplace hazards and give them a strong voice for their concerns, including safety issues. However, research is mixed as to whether this leads to lower injury rates (Kelloway 2004).

The evidence regarding the relationship between job involvement, defined as the extent to which one identifies with their job, and injuries is also mixed (Frone et al. 1995; Probst 2000), although high job involvement is generally associated with better psychological health (Lee \& Ashforth 1996).

Researchers have not yet studied how interpersonal conflict in work groups relates to accidents. However, lower interpersonal conflict is related to lower exposure to workplace aggression (Hershcovis et al. 2007), and perhaps not surprisingly, higher levels of interpersonal conflict at work are positively related to reports of strain and physical symptoms (Spector \& Jex 1998). One longitudinal study found interpersonal conflict to predict later psychological and physical health as well as work performance (Lubbers et al. 2005).

Most studies have found that work pressure, defined as the time pressure to complete tasks, is positively related to accidents, physical symptoms (Hinze 1988; Goldenhar et al. 2003), and injury severity (Gillen et al. 2002). In contrast, findings regarding the relationship between work pressure and psychological health are mixed (Frone et al. 1995; Lee \& Ashforth 1996). In jobs where workers have more control, psychological distress is less likely (Spector 1986; Van Der Doef \& Maes 1999).

Role overload, the degree to which one has too many tasks to do, has been positively associated with work-related accidents and injuries (Barling et al. 2002), and negatively related to psychological well-being (i.e., positively related to experiencing psychological symptoms) (Lee \& Ashforth 1996).

Table 1 summarizes the relationships between the health and safety outcomes and the individual and situational factors discussed above. Again, we make no prediction about the relative strength of each predictor. 


\section{RESEARCH METHODOLOGY}

Between 2004 and 2006, data were collected from construction workers at 84 non-residential construction sites across Ontario. Sites were identified in many ways, including construction association membership directories, building permit documents, and visiting active sites. Once permission to access the site was received, a research team went to the site to meet with the workers and collect the data. Typically, this took place during a coffee break or organized meeting (e.g. safety meetings).

Table 1: Summary of literature review

\begin{tabular}{|c|c|c|c|}
\hline & $\begin{array}{l}\text { Number of } \\
\text { Physical } \\
\text { Symptoms }\end{array}$ & $\begin{array}{c}\text { Number of } \\
\text { Psychological } \\
\text { Symptoms }\end{array}$ & $\begin{array}{l}\text { Number of } \\
\text { Incidents/ } \\
\text { Accidents }\end{array}$ \\
\hline \multicolumn{4}{|l|}{ Individual factors } \\
\hline Age & + & - & - \\
\hline Conscientiousness & - & 0 & - \\
\hline Safety consciousness & - & 0 & - \\
\hline Fatalism & 0 & + & $?$ \\
\hline \multirow{2}{*}{\multicolumn{4}{|c|}{$\begin{array}{l}\text { Situational Factors } \\
\text { Factors affecting safety climate: }\end{array}$}} \\
\hline & & & \\
\hline Coworker safety perception & 0 & - & $?$ \\
\hline Supervisor safety perception & 0 & - & $?$ \\
\hline Management safety perception & 0 & - & $?$ \\
\hline Safety program perception & 0 & - & $?$ \\
\hline Job Safety (low risk perception) & - & - & - \\
\hline Unionization & 0 & $?$ & $?$ \\
\hline Leadership & - & - & - \\
\hline Job involvement & 0 & - & 0 \\
\hline Interpersonal conflict at work & + & + & 0 \\
\hline Work pressure & + & ? & + \\
\hline Role overload & + & + & + \\
\hline
\end{tabular}

The protocol required the researchers to first explain the research objectives to the workers, to emphasize that their participation was voluntary, and that their responses would only be seen by the researchers. They were first provided a consent form, which they signed and dated. As each participant completed the consent form, it was placed in a collection box and the participant was then handed the questionnaire. Once the questionnaire was complete, it too was placed in the box and the participant left the room to return to work (i.e., consent forms and questionnaires were collected separately). When all papers were collected, the research team returned with the collection box.

In all, 911 construction workers completed the self-administered questionnaires. Each survey contained 105 questions and took approximately 15 minutes to complete. The sampling error was $+/-2.7 \%$ at $90 \%$ confidence, or $+/-4.3 \%$ at $99 \%$ confidence.

Each survey consisted of four sections: demographics, attitudes, health outcomes, and accident reporting. In addition to health outcomes, accidents, and the attitudinal scales previously discussed (Table 3), the demographic portion of the survey collected information on age, trade, years in construction, tenure with employer, number of employers and projects in the previous 3 years, hours worked per week in high and low season, job position, safety committee participation, and union membership. 


\section{CHARACTERISTICS OF THE SAMPLE}

Table 2 presents a summary of the demographic data, including the range of responses. Age was reasonably distributed across the skilled trades. Participants had a median of 2 employers in the previous 3 years, with median time with the current employer being 2.5 years.

Table 2: Responses to demographic questions

\begin{tabular}{lccc}
\hline Question & Range & Mean or \% & Median \\
\hline Age & 18 to 69 & 38.3 & 38 \\
Years in construction & 0.01 to 50 & 15.1 & 14 \\
Years with the present employer & 0.01 to 44 & 5.34 & 2.5 \\
Number of construction employers worked for in the last 3 years & 1 to 50 & 2.91 & 2 \\
Number of projects worked in the last 3 years & 1 to 120 & 10.8 & 5 \\
Average number of hours worked per week in high season & $4-90$ & 46.1 & 44 \\
Average number of hours worked per week in low season & $8-65$ & 37.7 & 40 \\
Served on a safety committee & Yes/No & $37.8 \%$ yes \\
Member of a union & Yes/No & $77.6 \%$ yes \\
& Supervisor & $26.9 \%$ & \\
Job position & Journeyman & $56.3 \%$ &
\end{tabular}

Factor scales for situational and individual variables consisted of a series of statements (between 4 and 10) that focused on each construct (Table 3). These scales were reliable and valid in previous studies, although nearly all of these previous samples did not involve construction workers. Based on published studies, we adapted items to the construction industry where necessary, and confirmatory factor analysis showed that these items related to the underlying constructs (principal components analysis - PCA). Scale reliability was verified using Cronbach's Alpha. Responses were scored on a Likert scale ranging from 1 (strongly disagree) to 5 (strongly agree), except for the F13, which had a 6-point scale in conformity with the original research (the responses were aggregated to determine a score for that factor).

Table 3: Attitudes

\begin{tabular}{|c|c|c|c|c|}
\hline & & Mean & Median & Summary \\
\hline & $\begin{array}{l}\text { Conscientiousness } \\
\text { (Goldberg 1992) }\end{array}$ & 4.12 & 4.1 & $\begin{array}{c}\text { Participants generally felt they were careful and } \\
\text { mindful when doing tasks. }\end{array}$ \\
\hline $\mathrm{F} 2$ & $\begin{array}{l}\text { Fatalism } \\
\text { (Williamson et al. 1997) }\end{array}$ & 2.47 & 2.5 & $\begin{array}{c}\text { They disagreed slightly that they had no control } \\
\text { over their own safety. }\end{array}$ \\
\hline F3 & $\begin{array}{l}\text { Safety consciousness } \\
\text { (Barling et al. 2002) }\end{array}$ & 4.12 & 4 & $\begin{array}{l}\text { Participants believed that they are aware of } \\
\text { relevant safety issues. }\end{array}$ \\
\hline F4 & $\begin{array}{l}\text { Leadership } \\
\text { (Barling et al. 2002) }\end{array}$ & 3.81 & 3.85 & $\begin{array}{l}\text { There is general satisfaction with leadership's } \\
\text { ability to influence and motivate workers. }\end{array}$ \\
\hline F5 & $\begin{array}{l}\text { Role overload } \\
\text { (Beehr et al. 1976) }\end{array}$ & 2.32 & 2 & $\begin{array}{l}\text { Participants generally disagreed that excessive } \\
\text { amounts of work are given to them. }\end{array}$ \\
\hline F6 & $\begin{array}{l}\text { Work pressure } \\
\text { (Glendon \& Litherland 2001) }\end{array}$ & 2.37 & 2 & $\begin{array}{l}\text { There is general disagreement that workers feel } \\
\text { they are pressured to work overly fast. }\end{array}$ \\
\hline F7 & $\begin{array}{l}\text { Job safety perception } \\
\text { (Hayes et al. 1998) }\end{array}$ & 2.30 & 2 & There is disagreement that their job is safe. \\
\hline F8 & $\begin{array}{l}\text { Coworker safety perception } \\
\text { (Hayes et al. 1998) }\end{array}$ & 3.46 & 3.5 & $\begin{array}{c}\text { There is a slight agreement that coworkers' } \\
\text { behaviour is generally safe. }\end{array}$ \\
\hline F9 & $\begin{array}{l}\text { Supervisor safety perception } \\
\text { (Hayes et al. 1998) }\end{array}$ & 3.84 & 4 & $\begin{array}{l}\text { There is agreement that supervisors have good } \\
\text { attitudes and behave in a safe manner. }\end{array}$ \\
\hline F10 & $\begin{array}{l}\text { Management safety percep'n } \\
\text { (Hayes et al. 1998) }\end{array}$ & 3.77 & 3.86 & $\begin{array}{l}\text { There is agreement that management has a good } \\
\text { attitude and behaves in a safe manner. }\end{array}$ \\
\hline
\end{tabular}




\begin{tabular}{|c|c|c|c|}
\hline & Mean & Median & Summary \\
\hline $\begin{array}{l}\text { F11 Safety program perception } \\
\text { (Hayes et al. 1998) }\end{array}$ & 3.95 & 4 & $\begin{array}{l}\text { There is a general agreement that safety } \\
\text { programs and policies are useful and clear. }\end{array}$ \\
\hline $\begin{array}{l}\text { F12 Interpersonal conflict at work } \\
\text { (Spector \& Jex 1998) }\end{array}$ & 1.84 & 1.71 & $\begin{array}{l}\text { Participants do not report many conflicts at work } \\
\text { with coworkers and supervisors. }\end{array}$ \\
\hline $\begin{array}{l}\text { F13 Job involvement (1-6) } \\
\text { (Kanungo 1982) }\end{array}$ & 3.92 & 4 & $\begin{array}{l}\text { There is some agreement that their job plays an } \\
\text { important role in their life. }\end{array}$ \\
\hline
\end{tabular}

Table 4 shows the items that measured physical symptoms, psychological symptoms, and accidents (Barling et al. 2002). Workers were asked to report the number of times they experienced each occurrence in the past 3 months (based on norms in the psychological literature, it is assumed that workers can accurately recall events in the past 3 months). It is important to note that these measures were based on previous research in other industries and no attempt was made to associate accidents with symptoms. A headache may be due to fumes, a fall, or poor posture. Associating the cause with a symptom was not within the scope of this project.

Table 5 shows the health and safety outcomes experienced in the previous 3 months. Only 87 respondents out of 911 reported no symptoms or accidents, resulting in approximately $90 \%$ of the respondents experiencing at least one outcome.

Table 4: Health and safety outcomes predicted

\begin{tabular}{lll}
\hline Physical symptoms & Psychological symptoms & Incidents/Accidents \\
\hline headache/dizziness & lost sleep due to work-related & exposure to chemicals \\
persistent fatigue & worries & overexertion while \\
respiratory injuries & unable to concentrate on work & handling/lifting/carrying \\
strains/sprains & tasks & trap by something \\
cut/puncture & unable to enjoy day-to-day & collapsing/caving/overturning \\
temporary loss of hearing & activities & slip/trip/fall on same level \\
eye injury & felt constantly under strain & struck against something \\
electrical shock & losing confidence in self & stationary \\
dislocated/fractured bone & felt incapable of making & struck by moving vehicle \\
skin rash/burn & decisions & struck by falling/flying objects \\
hernia & & contact with moving machinery \\
& & fall from height
\end{tabular}

To examine relationships with the outcomes experienced, the demographic factors were split into quartiles and the average outcome recalculated for each quartile (Table 6; only correlations significant at the 0.05 level are shown).

Table 5: Descriptive Statistics for Health and Safety Outcomes

\begin{tabular}{ccccc}
\hline Outcome Variable & Mean & Median & Yes (\%) & No (\%) \\
\hline Number of physical symptoms & 5.83 & 4 & $81.3 \%$ & $18.7 \%$ \\
Number of psychological symptoms & 3.57 & 1 & $54.8 \%$ & $45.2 \%$ \\
Number of accidents & 3.38 & 2 & $65.9 \%$ & $34.1 \%$
\end{tabular}

Age was negatively related to all three outcomes predicted. In particular, this data confirms that young workers experience more accidents than older workers (CSAO 2004b). The mean number of accidents in the $4^{\text {th }}$ age quartile was approximately half of the first quartile across all outcomes. The trend between accidents and years in construction mirrored age closely. It is interesting to note that no significant relationship existed between construction experience and psychological symptoms. As workers spent more time with an employer, the physical 
symptoms and accidents they experienced decreased. The visible difference was between the respondents that had been with their employer for more than seven years. Interestingly, hours per week during the high season had no relationship with physical symptoms or accidents. This may be due to the timing of the data collection. For example, if the data were not collected during the high season, then the worker's responses for the number of experienced injuries and symptoms would not reflect their experience during the high season. Supervisors reported experiencing the most psychological symptoms. Interestingly, the prevalence of psychological symptoms was also greater among the non-union workers.

Table 6: Prevalence by Demographic Factors

\begin{tabular}{|c|c|c|c|}
\hline \multirow{2}{*}{ Factor Quartiles } & \multicolumn{3}{|c|}{ Health and Safety Outcomes } \\
\hline & $\begin{array}{l}\text { Physical } \\
\text { Symptoms }\end{array}$ & $\begin{array}{l}\text { Psychological } \\
\text { Symptoms }\end{array}$ & Accidents \\
\hline \multicolumn{4}{|c|}{ Gymploms } \\
\hline$\leq 29$ & 7.94 & 4.43 & 4.65 \\
\hline $30-38$ & 6.60 & 3.59 & 3.87 \\
\hline $39-45$ & 5.34 & 3.48 & 2.72 \\
\hline$\geq 46$ & 3.82 & 2.39 & 2.51 \\
\hline \multicolumn{4}{|l|}{ Years in construction } \\
\hline$\leq 5$ & 7.21 & & 3.88 \\
\hline $5-14$ & 6.27 & & 3.99 \\
\hline $15-22$ & 5.85 & & 3.32 \\
\hline$\geq 23$ & 4.50 & & 2.77 \\
\hline \multicolumn{4}{|l|}{ Years with employer } \\
\hline Under 1 & 6.57 & & 4.15 \\
\hline $1-2.5$ & 6.36 & & 4.02 \\
\hline $2.5-7$ & 6.46 & & 3.27 \\
\hline Over 7 & 4.35 & & 2.45 \\
\hline \multicolumn{4}{|c|}{ No. employers in 3 yrs } \\
\hline 1 & 5.88 & & 3.08 \\
\hline 2 & 4.87 & & 3.20 \\
\hline 3 & 6.42 & & 3.59 \\
\hline Over 3 & 7.59 & & 4.77 \\
\hline \multicolumn{4}{|c|}{ Hrs/week high season } \\
\hline Under 40 & & 2.69 & \\
\hline $40-50$ & & 3.57 & \\
\hline Over 50 & & 4.65 & \\
\hline \multicolumn{4}{|l|}{ Hrs/week low season } \\
\hline Under 40 & 3.34 & & 4.01 \\
\hline $40-50$ & 3.21 & & 3.68 \\
\hline Over 50 & 3.81 & & 3.21 \\
\hline \multicolumn{4}{|l|}{ Job position } \\
\hline Supervisor & 4.52 & 5.13 & 2.48 \\
\hline Journeyman & 6.33 & 2.89 & 3.69 \\
\hline Apprentice & 7.37 & 4.16 & 4.53 \\
\hline \multicolumn{4}{|l|}{ Union Membership } \\
\hline Yes & & 3.21 & \\
\hline No & & 4.81 & \\
\hline \multicolumn{4}{|l|}{ Supervisors } \\
\hline Union & & 4.03 & \\
\hline Non-Union & & 6.99 & \\
\hline
\end{tabular}




\section{CONSTRUCTION WORKERS' HEALTH}

Outcome data were transformed into binary values indicating whether or not the worker experienced at least one safety or health outcome. Given the cross-sectional nature of this data, it is not possible to determine causality. The questionnaire was set up to gather data on attitudes at a particular moment, and the occurrence of incidents for the previous 3 months. Therefore, in the following discussion, consideration will be given that causation could flow in either direction (from attitudes to outcomes or vice versa; workers attitudes could also be formed by their health and safety experiences).

\section{Physical Symptoms}

The results in Table 7 show that workers reporting at least one physical symptom were younger, less experienced, and had shorter job tenure. Symptom rates decreased with job position, but remained high nonetheless. Those reporting a physical symptom had more negative attitudes toward their perceptions of job safety and job involvement, and reported experiencing more work pressure.

\section{Psychological symptoms}

Workers reporting at least one psychological symptom were somewhat younger and worked more hours per week in high season (Table 8). More supervisors and apprentices experienced at least one psychological symptom than journeymen. Two thirds of non-union workers experienced at least one psychological symptom whereas only half of union workers did. Those reporting psychological symptoms tended to feel a bit more work overload, pressure, and conflict in their jobs (possibly related to the higher number of hours worked weekly) (Williamson et al. 1997). They also had a more negative perception of their coworkers' safety behaviour. These are not surprising findings, however they do show the extent to which psychological problems are manifested. The number of years spent with the current employer, or the number of employers in the previous 3 years do not have significant relationships with psychological symptoms.

Table 7: Significant factors by physical symptom

\begin{tabular}{|c|c|c|c|}
\hline \multirow{2}{*}{\multicolumn{2}{|c|}{ Factors }} & \multicolumn{2}{|c|}{ Physical Symptom } \\
\hline & & Yes & No \\
\hline \multicolumn{2}{|l|}{ Age } & 37.5 & 41.1 \\
\hline \multicolumn{2}{|c|}{ Years in construction } & 14.4 & 16.7 \\
\hline \multicolumn{2}{|c|}{ Years with current employer } & 5.1 & 6.1 \\
\hline \multicolumn{2}{|c|}{ No. employers in last 3 years } & 3.0 & 2.4 \\
\hline \multirow[t]{3}{*}{ Job position } & Supervisors & $71 \%$ & $29 \%$ \\
\hline & Journeymen & $80 \%$ & $20 \%$ \\
\hline & Apprentices & $93 \%$ & $7 \%$ \\
\hline \multicolumn{2}{|c|}{ Job involvement } & 3.87 & 4.17 \\
\hline \multicolumn{2}{|c|}{ Job risk perception } & 2.24 & 2.64 \\
\hline \multicolumn{2}{|c|}{ Work pressure } & 2.39 & 2.14 \\
\hline
\end{tabular}

Table 8: Significant factors by psychological symptoms

\begin{tabular}{|c|c|c|c|}
\hline \multirow{2}{*}{\multicolumn{2}{|c|}{ Factors }} & \multicolumn{2}{|c|}{ Psychological Symptom } \\
\hline & & Yes & No \\
\hline \multicolumn{2}{|c|}{ Age (years) } & 36.8 & 39.6 \\
\hline \multicolumn{2}{|c|}{ Hours/week in high season } & 47.2 & 44.7 \\
\hline \multirow[t]{3}{*}{ Job position } & Supervisors & $57 \%$ & $43 \%$ \\
\hline & Journeymen & $48 \%$ & $52 \%$ \\
\hline & Apprentices & $60 \%$ & $40 \%$ \\
\hline \multirow[t]{2}{*}{ Union membership } & Yes & $52 \%$ & $48 \%$ \\
\hline & No & $65 \%$ & $35 \%$ \\
\hline \multicolumn{2}{|c|}{ Coworker safety perception } & 3.33 & 3.64 \\
\hline
\end{tabular}


Interpersonal conflict

$\begin{array}{ll}1.98 & 1.66 \\ 2.20 & 2.46 \\ 2.47 & 2.09 \\ 2.52 & 2.15\end{array}$

\section{ACCIDENTS/INCIDENTS}

Table 9 illustrates that workers experiencing at least one accident in the previous 3 months were somewhat younger and less experienced, with shorter job tenure. Supervisors were almost twice as likely as apprentices to avoid any accidents. Those experiencing accidents also reported lower job involvement and job safety perceptions (equivalent to a higher perception of risk), and felt more pressure to work fast. They had less confidence in the safety commitment of their supervisors and employers, and in the ability of leadership to influence safety. Although we cannot determine causality, if one assumes accidents are predicting attitudes, it is possible that within a certain amount of time of having an accident, attitudes improve as the worker regains confidence and the perception of control over safety. If this is the case, the supervision environment could be important in shortening this cycle. If one assumes attitudes are predicting accidents the potential for intervention is even greater.

\section{FIRST ANALYTICAL APPROACH: REGRESSION}

Linear regression prediction models were tested based on previous findings of significant correlations of all factors with the outcome variables. Regression was run using both 'Enter' and 'Stepwise' methods for introducing the independent variables in the model (normality requirements for the dependent variable were violated for all three variables, and therefore the models could be weak or unreliable).

Table 9: Significant factors by accident occurrence

\begin{tabular}{lcc}
\hline Factors & \multicolumn{2}{c}{ Accident/Incident } \\
& Yes & No \\
\hline Age & 36.8 & 40.6 \\
Time in construction & 14.1 & 16.3 \\
Time with current employer & 4.8 & 6.2 \\
No. employers in last 3 years & 2.9 & 3.1 \\
Job position $\quad$ Supervisors & $63 \%$ & $37 \%$ \\
\multicolumn{4}{l}{ Job involvement $\quad$ Apprentices } & $66 \%$ & $34 \%$ \\
Job safety perception & $79 \%$ & $21 \%$ \\
Leadership & 3.78 & 4.19 \\
Management safety perception & 2.18 & 2.58 \\
Supervisor safety perception & 3.7 & 4.01 \\
Work pressure & 3.66 & 3.99 \\
& 3.73 & 4.05 \\
& 2.46 & 2.13
\end{tabular}

Table 10: Linear regression model predictors

\begin{tabular}{|c|c|c|c|c|c|}
\hline \multicolumn{2}{|c|}{$\begin{array}{c}\text { Number of physical } \\
\text { symptoms }\end{array}$} & \multicolumn{2}{|c|}{$\begin{array}{c}\text { Number of psychological } \\
\text { symptoms }\end{array}$} & \multicolumn{2}{|c|}{ Number of accidents } \\
\hline Predictor & $\begin{array}{c}\text { B } \\
\text { coeff }\end{array}$ & Predictor & $\begin{array}{c}\text { B } \\
\text { coeff }\end{array}$ & Predictor & B coeff \\
\hline Constant & 17.087 & Constant & -0.612 & Constant & 9.429 \\
\hline Age & -0.095 & Age & -0.043 & Age & -0.045 \\
\hline Years w/ employer & -0.051 & Hr/week -high season & 0.042 & Interpersonal conflict & 1.644 \\
\hline Work pressure & -0.856 & Interpersonal conflict & 1.286 & Job safety (risk perc.) & -0.618 \\
\hline Job safety (risk perc.) & 1.884 & Management safety & -0.847 & Leadership & -0.781 \\
\hline Coworker safety & -1.254 & Role overload & 1.018 & Management Safety & -0.649 \\
\hline
\end{tabular}




\begin{tabular}{|c|c|c|c|c|c|}
\hline $\begin{array}{l}\text { Interpersonal conflict } \\
\text { Job safety (risk perc.) } \\
\text { Work pressure }\end{array}$ & 0.780 & $\begin{array}{l}\text { Safety program } \\
\text { Work pressure }\end{array}$ & $\begin{array}{l}0.947 \\
1.075\end{array}$ & Safety consciousness & 0.595 \\
\hline $\begin{array}{l}\mathrm{R}=0.545 \\
\mathrm{Ra}^{2}=0.284\end{array}$ & & $\begin{array}{l}\mathrm{R}=0.490 \\
\mathrm{Ra}^{2}=0.230\end{array}$ & & $\begin{array}{l}\mathrm{R}=0.499 \\
\mathrm{Ra}^{2}=0.234\end{array}$ & \\
\hline
\end{tabular}

For all tests, the ANOVA F-statistic was significant, showing that $\mathrm{R}$ and the regression models were statistically significant. As shown in Table 10, the best variance explanation is offered for physical symptoms (28.4\% variance explained by the model), then for number of accidents (23.4\%), and lastly for psychological symptoms (23\%). Although these models do not explain large amounts of variance in the dependant variables, it should be noted that engineering faults typically only explain $10 \%$ of the variance in accidents (Vredenburgh 2002). Hence, these numbers could be viewed as noteworthy in comparison.

Only age and interpersonal conflict were significant across all three outcomes. Work pressure predicted both psychological and physical symptoms. Perceptions of management's attitudes toward safety predicted both psychological symptoms and accidents.

\section{SECOND ANALYTICAL APPROACH: PROBABILISTIC MODELING}

An alternative means of interpreting these data is through a Bayesian belief network $(B N)$. $A$ $\mathrm{BN}$ is a graphical representation of conditional dependence among a group of variables. Embedded is a probabilistic approach to determine the likelihood of occurrence of certain variable conditions based upon Bayes' Theorem.

A BN consists of nodes, which represent variables, and directional arcs (arrows), which represent conditional dependence relationships between those nodes in such a way that the node at the tail of the arrow (the parent) affects the node to which the arrow points (the child). Although the interpretation of causation is not entirely accurate (causation is uni-directional, but Bayes' theorem is symmetric and bi-directional), the terms cause and effect are often used. A conditional probability is the likelihood of a state of a variable that is dependent on the state of another variable (Jensen 1996; McCabe et al. 1998). Bayes' Theorem $P(A \wedge B)=P(B \mid A)^{*} P(A)=P(A \mid B)^{*} P(B)$ is used to revise the probability of the state of a node depending on the evidence introduced for another variable.

Advantages of the belief network as a model are:

- Belief networks are excellent modeling environments for situations where there are conditional or influential relationships. Belief networks can integrate data and expert opinion seamlessly. Where data are missing or are not collectable, BN may be developed using expert knowledge (Charniak 1991).

- The structure of a network is very intuitive, and domain experts do not need to understand the background theory to be able to participate in knowledge elicitation.

- The models are symmetric in that evidence can be entered at any node, and all remaining nodes are recalculated. You can get the probability of any node. There is no directional constraint on the logic once it has been developed. For example, a belief network developed for the diagnostics (called diagnostic inference) of equipment breakdowns would also provide information about the symptoms of a malfunction, given the cause of the breakdown (called causal inference) without redeveloping the network. In other words, the belief network has the inherent ability to reverse its logic.

- The model represents the processes that occur, rather than an expert's perception of the factors that are at play and their importance. Belief networks have been found to be more effective than rule-based expert systems for capturing knowledge when exceptions to the 
rules are too important to exclude, but too numerous to express explicitly (Chong and Walley 1996).

- Changes to the model are isolated to the nodes that physically adjoin the changes in the network.

The limitations of belief networks are:

- The difficulty of collecting data and/or expert knowledge in a consistent and unbiased manner, and translating it to nodes, arrows, and probabilities.

- Networks cannot handle continuous variables under today's technology, but that is slowly changing.

Based on the data collected, a probabilistic model shown in Figure 3 was developed. Microsoft Belief Network@ 1.001 was the modeling environment software. The network has 21 variables and 36 connections. The connections were based on the strength of the correlation and were limited to three parents per variable with the exception of accident and psychological symptom, which have 4 parents.

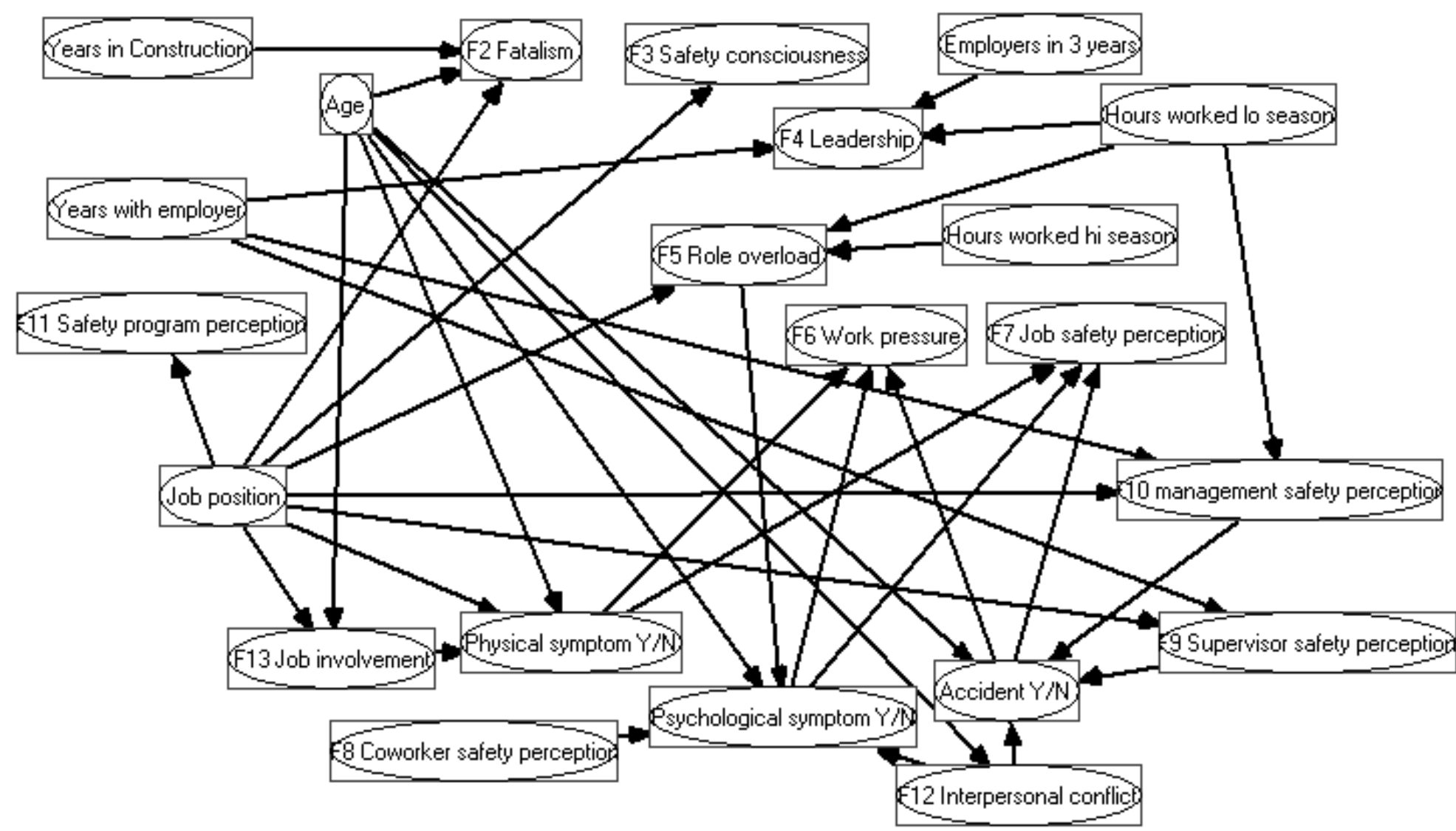

Figure 3: Probabilistic Model

Job position and age have the most influence in the network, with connections to 8 and 6 variables respectively. Several attitudinal factors did not relate to outcomes. Note that work pressure and job safety perception are children (and not parents) of the outcome variables. They were modeled this way for 2 reasons. First, these attitudinal factors did not have demographic parents i.e. no demographic variables had sufficient correlation with these two factors to identify them as a parent. Attitudes are often a result of experiences and environmental influences, and it may have been odd to model them as orphans (i.e. no 
parents). Second, turning the arrows around reduced the number of parents on the incident variables. Given the symmetry of Bayes' Theorem and the relative simplicity of the model, this should not affect its performance or logic.

Six variables were not included in the model, namely, number of projects in previous 3 years, union membership, safety training, safety committee, trade, and conscientiousness. Their relationships to the other variables were not strong enough to warrant inclusion, and removing them did not affect model performance. Joint probability tables were extracted from the collected data. The conditional probabilities were checked for accuracy relative to the data, as shown in Table 11. The difference between the data and the model is less than $5 \%$ in all cases.

To verify the model, several cases were developed that might represent a common scenario. Each case was tested, and the likelihood of experiencing an incident was evaluated by the network (Table 12). Cases $\mathrm{G}$ and $\mathrm{H}$ represent opposing attitudes toward interpersonal conflict, the safeness of their job, and their management's safety awareness. Changes in attitude from negative to positive represent a $25 \%$ decrease in accidents and $12 \%$ decrease in physical symptoms!

Table 11: Prior Probability Verification

\begin{tabular}{lccc}
\hline & \multicolumn{3}{c}{ Percent that Disagree $<3$} \\
Attitudinal factors & Data & BN Model & Difference \\
\hline Coworker safety perception & $18 \%$ & $18 \%$ & 0 \\
Fatalism & $69 \%$ & $70 \%$ & 1 \\
Interpersonal conflict at work & $93 \%$ & $96 \%$ & 3 \\
Job involvement & $19 \%$ & $21 \%$ & 2 \\
Job safety perception & $71 \%$ & $71 \%$ & 0 \\
Leadership & $9 \%$ & $10 \%$ & 1 \\
Management safety perception & $10 \%$ & $11 \%$ & 1 \\
Role overload & $70 \%$ & $72 \%$ & 2 \\
Safety consciousness & $3 \%$ & $3 \%$ & 0 \\
Safety program perception & $6 \%$ & $5 \%$ & 1 \\
Supervisor safety perception & $7 \%$ & $10 \%$ & 3 \\
Work pressure & $72 \%$ & $72 \%$ & 0 \\
Outcomes & Percent that experienced $\mathbf{1}$ or more: \\
Physical symptoms & $81 \%$ & $79 \%$ & 2 \\
Psychological symptoms & $55 \%$ & $59 \%$ & 4 \\
Accident - Yes & $66 \%$ & $68 \%$ & 2
\end{tabular}

Table 12: Verification cases

\begin{tabular}{|c|c|c|c|c|c|}
\hline \multirow[b]{2}{*}{ Case } & \multirow[b]{2}{*}{ Worker characteristic } & & \multicolumn{3}{|c|}{ Percentage experiencing at least one: } \\
\hline & & & $\begin{array}{l}\text { Physical } \\
\text { symptom }\end{array}$ & $\begin{array}{c}\text { Psycho- } \\
\text { logical } \\
\text { symptom }\end{array}$ & Accident \\
\hline A & No evidence & & $79 \%$ & $59 \%$ & $68 \%$ \\
\hline $\mathrm{B}$ & Age & $18-29$ & $80 \%$ & $61 \%$ & $75 \%$ \\
\hline C & Age & $18-29$ & & & \\
\hline & $\begin{array}{l}\text { Years with employer } \\
\text { Job position }\end{array}$ & $\begin{array}{l}0-1 \\
\text { apprentice }\end{array}$ & $93 \%$ & $61 \%$ & $75 \%$ \\
\hline $\mathrm{D}$ & Age & $46-69$ & & & \\
\hline & $\begin{array}{l}\text { Years with employer } \\
\text { Job position }\end{array}$ & $\begin{array}{l}>7 \\
\text { supervisor }\end{array}$ & $66 \%$ & $56 \%$ & $62 \%$ \\
\hline$E$ & Age & $30-38$ & $83 \%$ & $60 \%$ & $71 \%$ \\
\hline
\end{tabular}




\begin{tabular}{|c|c|c|c|c|}
\hline Years with employer & \multicolumn{4}{|l|}{$0-1$} \\
\hline $\begin{array}{l}\text { Age } \\
\text { Years with employer }\end{array}$ & $\begin{array}{l}30-38 \\
>7\end{array}$ & $77 \%$ & $61 \%$ & $63 \%$ \\
\hline Interpersonal conflict & $<3$ low & & & \\
\hline $\begin{array}{l}\text { Job safety perception } \\
\text { Management safety perception }\end{array}$ & $\begin{array}{l}>3 \text { safe } \\
>3 \text { high }\end{array}$ & $72 \%$ & $60 \%$ & $54 \%$ \\
\hline $\begin{array}{l}\text { Interpersonal conflict } \\
\text { Job safety perception } \\
\text { Management safety perception }\end{array}$ & $\begin{array}{l}>3 \text { high } \\
<3 \text { unsafe } \\
<3 \text { low }\end{array}$ & $84 \%$ & $62 \%$ & $79 \%$ \\
\hline
\end{tabular}

Alternatively, we can look at the impact other factors have on attitudes, as shown in Table 13. Here we see that workers have three times the likelihood of feeling work pressure if they experience incidents than if they do not. They are twice as likely to have good job safety perception if they do not experience an incident, and twice as likely to feel role overload if they have physical and psychological symptoms.

In summary, this model provides a novel way of interpreting the data and allows users to determine the effects of combinations of changes on the sample data. Relationships between variables are shown both qualitatively (by graphical connection) and quantitatively (by probabilities).

Table 13: Attitudes Given Incidents

\begin{tabular}{|c|c|c|c|c|}
\hline Attitudes & $\begin{array}{c}\text { A } \\
\text { no } \\
\text { evidence }\end{array}$ & $\begin{array}{c}\text { B } \\
\text { Age 18-29 } \\
0-1 \text { Yrs with } \\
\text { employer } \\
\text { At least one } \\
\text { each: physical, } \\
\text { psychological } \\
\text { symptom and } \\
\text { accident }\end{array}$ & $\begin{array}{c}\text { C } \\
\text { Age 39-45 } \\
\text { 2.5-7 Years } \\
\text { with employer } \\
\text { No accident, } \\
\text { physical or } \\
\text { psychological } \\
\text { symptom }\end{array}$ & $\begin{array}{c}\text { D } \\
\text { At least one } \\
\text { physical and } \\
\text { psychological } \\
\text { symptom }\end{array}$ \\
\hline Fatalism & $30 \%$ & $28 \%$ & $27 \%$ & $31 \%$ \\
\hline Safety consciousness & $97 \%$ & $97 \%$ & $97 \%$ & $97 \%$ \\
\hline Leadership & $90 \%$ & $87 \%$ & $93 \%$ & $90 \%$ \\
\hline Role overload & $28 \%$ & $26 \%$ & $15 \%$ & $34 \%$ \\
\hline Work pressure & $28 \%$ & $37 \%$ & $13 \%$ & $29 \%$ \\
\hline Job safety perception & $29 \%$ & $24 \%$ & $46 \%$ & $36 \%$ \\
\hline Coworker safety perception & $82 \%$ & $78 \%$ & $79 \%$ & $80 \%$ \\
\hline Supervisor safety perception & $89 \%$ & $79 \%$ & $97 \%$ & $92 \%$ \\
\hline Management safety perception & $89 \%$ & $89 \%$ & $97 \%$ & $94 \%$ \\
\hline Safety program perception & $95 \%$ & $94 \%$ & $95 \%$ & $94 \%$ \\
\hline Interpersonal conflict & $4 \%$ & $7 \%$ & $7 \%$ & $4 \%$ \\
\hline Job involvement & $79 \%$ & $78 \%$ & $80 \%$ & $79 \%$ \\
\hline
\end{tabular}

\section{CONCLUSIONS}

The aim of this research was to document relationships between demographics, attitudes toward safety, accidents, psychological, and physical health in Ontario construction workers. In terms of the demographic and individual predictors that related to accidents, psychological, and physical health, what we did not find is perhaps as significant as what we did find.

Six variables on which we collected data were not included in the Bayesian Network because their relationships to other variables in the network were not strong enough to warrant inclusion and removing them did not affect model performance (i.e., the number of projects worked on in the previous 3 years, union membership, safety training, participation in safety committees, 
trade, and/or conscientiousness). In regard to both conscientiousness and union membership, these findings are not what the literature would predict and leave questions for future research.

The Bayesian network also allowed for an interesting insight into "profiling" who is most likely to be injured at work (Table 12, case $\mathrm{G}$ versus $\mathrm{H}$ ). We see that an individual experiencing low interpersonal conflict at work who also has low perceptions of risk (high job safety) and positive perceptions of management's attitudes toward safety was about $25 \%$ less likely to have experienced a workplace accident than someone who is experiencing high interpersonal conflict at work and also has negative perceptions of both job safety and management's attitudes toward safety.

Another way of looking at these relationships using the network is that whereas individual personality variables such as fatalism and conscientiousness made little difference in indicating whether or not a construction worker experienced health and safety outcomes, those experiencing at least one of each outcome were three times as likely to feel work pressure and half as likely to perceive their job as safe (Table 13).

These are interesting findings with considerable value to an HR department trying to reduce workplace accidents. Surveying work groups on a few key variables could be enough to substantially reduce accidents on the job.

In terms of predicting health and safety outcomes using the regression models, it should be noted that engineering faults typically explain about $10 \%$ of the variance in accidents (Vredenburgh 2002). In contrast, our regression models explained between approximately 23\% (for both accidents and psychological symptoms) and $28 \%$ of the variance in the dependent variables (for physical symptoms).

Two predictor variables in the regression models were significant across at least two outcomes. Work pressure predicted both psychological and physical symptoms. Perceptions of management's attitudes toward safety predicted both accidents and physical symptoms. These findings are not particularly surprising; Work pressure can lead to frustration, anxiety, and depression all of which can lead to both psychological and physical symptoms over time (Glendon \& Litherland 2001; Spector \& Jex 1998). These relationships also confirm previous findings in other contexts (Barling et al. 2002) demonstrating the important relationship between management's attitudes and accidents.

In terms of predicting outcomes, however, the regression models demonstrated that only the age of constructions workers and the degree of interpersonal conflict at work were important in predicting all three outcomes. Younger workers and those experiencing more conflict at work had more psychological and physical symptoms as well as accidents.

Table 6 illustrated that across all three outcomes, means in the youngest quartile of workers (less than 29 years) were approximately double those in the oldest quartile (older than 46 years). This finding supports previous reports about accidents (CSAO 2004b) and extends this knowledge to both psychological and physical health. It also suggests where health and safety programs need to be targeted. These findings would direct contractor safety programs to focus on youth, apprentices, and short-term employees in particular.

In terms of interpersonal conflict, these findings are particularly interesting. A recent longitudinal study linked the interpersonal workplace conflict experienced by young workers in other industries to their subsequent psychological and physical health as well as work performance (Lubbers et al. 2005). To our knowledge researchers have not yet studied how interpersonal conflict in work groups relates to accidents, and our findings would appear to 
extend this link. Future research will want to consider the mechanism responsible for this relationship (diminished vigilance due to cognitive distraction).

\section{ACKNOWLEDGEMENTS}

This research was supported by WSIB Grant \#03026. We are grateful to all of the managers, safety coordinators, and workers who participated in this study. Special thanks go to those who took extra time to share their experiences and insight. The research team included:

Research Collaborators:

Doug McVittie, Construction Safety Association of Ontario

Gary Robertson, Consultant
Research Assistants:

Yusuf Colombowala

Dimitrios Karahalios

Ramona Munteanu

Sean Tucker
Field Assistants:

James Goldenberg

Ken Huen

Andrew Lam

Daniel Ludwin

\section{REFERENCES}

Barling, J., Kelloway, K., Sivanathan, N., Turner, N., and Loughlin, C. 2005. Leading others to well-being: direct and indirect effects of transformational leadership. In C. Mason, S. Parker, and M. Griffin (Chairs), Transformational leadership: From leader interventions to team outcomes, Symposium at the 65th annual meeting of the Academy of Management, Honolulu, HI. USA.

Barling, J., and Frone, M. (Eds.). 2004. The psychology of workplace safety. American Psychological Association, Washington, D.C.

Barling J., Kelloway E.K., and Iverson R.D. 2003. Accidental outcomes: attitudinal consequences of workplace injuries. Journal of Occupational Health Psychology, 8(1): 74-85.

Barling, J., Loughlin, C., and Kelloway, E.K. 2002. Development and test of a model linking safety-specific transformational leadership and occupational safety. Journal of Applied Psychology 87(3): 488-496.

Baugher, J.E. and Roberts, J.T. 1999. Perceptions and worry about hazards at work: unions, contract maintenance, and job control in the US. Industrial Relations, 38(4): 522-540.

Baugher, J. E. 2004. Workplace hazards, unions, and coping styles. Labour Studies Journal 29(2): 83-106.

Beehr, T., Walsh, J., and Taber, T. 1976. Relationship of stress to individually and organizationally valued states: higher order needs as a moderator. Journal of Occupational Psychology 61: 41-47.

Bender, K.A., and Sloane, P.J. 1998. Job satisfaction, trade unions and exit-voice revisited. Industrial and Labour Relations Review, 51(2): 222-241.

Bird, F. 1974. Management guide to loss control. International Safety Academy, Houston, Texas USA.

Carr J.Z., Schmidt, A.M., Ford, J.K. and Deshon, R.P. 2003. Climate perceptions matter: a meta-analytic path analysis relating molar climate, cognitive and affective states, and individual level work outcomes. Journal of Applied Psychology, 88(4): 605-619.

Charniak, E. 1991. Bayesian networks without tears. Al Magazine, 12(4): 55-63.

Chong, H.G., and Walley, W.J. 1996. Rule-based versus probabilistic approaches to the diagnosis of faults in wastewater treatment processes. Artificial Intelligence in Engineering, 1:265-273.

Clarke S. 2006. The relationship between safety climate and safety performance: a metaanalytic review. Journal of Occupational Health Psychology, 11(4): 315-327.

Clarke, S., and Robertson, I.T. 2005. A meta-analytic review of the big five personality factors and accident involvement in occupational and non-occupational settings. Journal of Occupational and Organizational Psychology, 78(3): 355-376. 
Cooper, M.D. 1998. Improving safety culture: a practical guide. Wiley, Chichester, NY.

Coyle, I.R., Sleeman, S.D., and Adams, N. 1995. Safety climate. Journal of Safety Research 26: 247- 254.

CSAO. 2005. CSAO annual report 2005. Construction Safety Association of Ontario http://www.csao.org/UploadFiles/AnnualReport/Annual_Report_2005.pdf

CSAO. 2004a. CSAO annual report 2003. Construction Safety Association of Ontario, Etobicoke, Ontario, (www.csao.org)

CSAO. 2004b. CSAO's construction magazine - young workers special edition. Construction Safety Association of Ontario, Etobicoke, Ontario, www.csao.org - downloaded

Daniels, K. and Guppy, A. 1997. Stressors, locus of control, and social support as consequences of affective psychological well-being. Journal of Occupational Health Psychology, 2(2): 156-174.

Danna, K. and Griffin, R.W. 1999. Health and well-being in the workplace: a review and synthesis of the literature. Journal of Management, 25(3): 357-384.

Dedobbeleer, N., and Beland, F. 1991. A safety climate measure for construction sites. Journal of Safety Research 22: 97-103.

Flin, R., Mearns, P., O'Connor, P., and Bryden, R. 2000. Measuring safety climate: identifying the common features. Safety Science $34: 177-192$

Frone, M.R., Russell, M., and Cooper, M.L. 1995. Job stressors, job involvement and employee health: a test of identity theory. Journal of Occupational and Organizational Psychology, 68(1): 1-11.

Gadd, S., and Collins, A.M. 2002. Safety culture: a review of the literature (HSL/2002/25). Health and Safety Laboratory, Sheffield, UK.

Gillen, M., Baltz, D., Gassel, M., Kirsch, L., and Vaccaro, D. 2002. Perceived safety climate, job demands, and coworker support among union and non-union injured construction workers. Journal of Safety Research, 33: 33-51.

Glendon, A.I. and Stanton, N.A. 2000. Perspectives on safety culture. Safety Science. 34: 193214.

Glendon, A.I., and Litherland, D.K. 2001. Safety climate factors, group differences, and safety behaviour in road construction. Safety Science 39: 157-188.

Goldberg, L.R. 1992. The development of markers for the big-five factor structure. Psychological Assessment 4(1): 26-42.

Goldenhar, L.M., Williams, L.J., and Swanson, N.G. 2003. Modelling relationships between job stressors and injury and near-miss outcomes for construction labourers. Work \& Stress, 17(3): 218-240.

Grant, S., and Langan-Fox, J. 2007. Personality and the occupational stressor-strain relationship: the role of the big five. Journal of Occupational Health Psychology, 12(1): 20-33.

Harrell, W.A. 1995. Accident history and perceived risk of injury as factors influencing fatalism about occupational accidents. Perceptual and Motor Skills, 81(2): 665-666.

Hayes, B.E., Perander, J., Smecko, T., and Trask, J. 1998. Measuring perceptions of workplace safety: development and validation of the work safety scale. Journal of Safety Research 29(3):145-161.

Hershcovis, M.S., Turner, N., Barling, J., Arnold, K.A., Dupré, K.E., Inness, M., LeBlanc, M.M., and Sivanathan, N. 2007. Predicting workplace aggression: a meta-analysis. Journal of Applied Psychology. 92(1): 228-238.

Hinze, J. 1981. Human aspects of construction safety. Journal of the Construction Division, 107(1): 61-72.

Hinze, J. 1987. Qualities of safe superintendents. Journal of Construction Engineering and Management, 113(1): 169-171.

Hinze, J., and Gordon, G. 1979. Supervisor-worker relationship affects injury rate. Journal of the Construction Division, 105(3): 253-262. 
Hinze, J., and Roboud, P. 1988. Safety on large building construction projects. Journal of Construction Engineering and Management, 114(2): 286-293.

Hofmann, D. A., and Morgeson, F.P. 2004. The role of leadership in safety. in J. Barling \& M. R. Frone (Eds.), The psychology of workplace safety, Washington, DC, APA. pp. 159180.

Jensen, F.V. 1996. An introduction to bayesian networks. University College London Press, London, UK. pp. 2-62.

Kanungo, R.N. 1982. Work alienation: an integrative approach. New York: Praeger.

Kelloway, E.K., Mullen, J., and Francis, L. 2006. Divergent effects of transformational and passive leadership on employee safety. Journal of Occupational Health Psychology, 11(1): 76-86.

Kelloway, K. 2004. Labor unions and occupational safety: conflict and cooperation. In Julian Barling and Michael R. Frone (Eds.). The Psychology of Workplace Safety, Washington, D.C., American Psychological Association. pp. 249-264

Kennedy, R., and Kirwan, B. 1998. Development of a hazard and operability-based method for identifying safety management vulnerabilities in high-risk systems. Safety Science. 30:249-274.

Korten, A. and Henderson, S. 2000. The Australian national survey of mental health and wellbeing. British Journal of Psychiatry, 177: 325-330.

Lee, R.T. and Ashforth, B.E. 1996. A meta-analytic examination of the correlates of the three dimensions of job burnout. Journal of Applied Psychology, 81(2): 123-133.

Loughlin, C. and Frone, M. 2004. Young workers' occupational safety. In J. Barling \& M. Frone, Psychology of workplace safety, Washington, D.C., American Psychological Association.

Lubbers, R., Loughlin, C., and Zweig, D. 2005. Common pathways to health and performance: job-self-efficacy and affect among young workers. Journal of Vocational Behavior, Volume 67, Issue 2, October 2005, pp. 199-214.

McCabe, B., AbouRizk, S.M., and Goebel, R. 1998. Belief networks for construction performance diagnostics. Journal of Computing in Civil Engineering, 12 (2):93-100.

Miller, R.L., Griffin, M.A., and Hart, P.M. 1999. Personality and organizational health: the role of conscientiousness. Work \& Stress, 13: 7-19.

Murray, M., Fitzpatrick, D., and O'Connell, C. 1997. Fishermen's blues: factors related to accidents and safety among Newfoundland fishermen. Work \& Stress, 11(3): 292-297.

Probst, T.M. 2000. Wedded to the job: moderating effects of job involvement on the consequences of job insecurity. Journal of Occupational Health Psychology, 5(1): 6373.

Reason, J. 1997. Managing the risks of organizational accidents. Aldershot, Ashgate, UK.

Reichers, A.E. and Schneider, B. 1990. Climate and culture: An evolution of constructs. Organizational climate and culture, Jossey-Bass, San Francisco, USA: Jossey-Bass: pp. 5-39.

Robinson, F., Ahmed, S., and Ayo, O. 2003. Results of a pilot study to examine the effective integration of apprentices into the industrial construction sector. Canadian Journal of Civil Engineering, 30(2): 391-406.

Salminen, S. 2004. Have young workers more injuries than older ones? an international literature review. Journal of Safety Research, 35: 513-521.

Schneider, B. 1975. Organizational climates: an essay. Personnel psychology, 28: 447-479.

Shannon, H.S., Mayr, J., and Haines, T. 1997. Overview of the relationship between organizational and workplace factors and injury rates. Safety Science, 26(3): 201-217.

Sosik, J.J. and Godshalk, V.M. 2000. Leadership styles, mentoring functions received, and jobrelated stress: a conceptual model and preliminary study. Journal of Organizational Behavior, 21(4): 365-390.

Spector, P.E., and Jex, S.M. 1998. Development of four self-report measures of job stressors and strain: interpersonal conflict at work scale, organizational constraints scale, 
quantitative workload inventory, and physical symptoms inventory. Journal of Occupational Health Psychology, 3(4):356-367.

Spector, P.E., and Jex, S.M. 1991. Relations of job characteristics from multiple data sources with employee affect, absence, turnover intentions, and health. Journal of Applied Psychology, 76(1): 46-53.

Spector, P. 1986. Perceived control by employees: a meta-analysis of studies concerning autonomy. Human Relations, 39: 1005-1016.

Tversky, A, and Kahneman, D. 1990. Judgment under uncertainty: heuristics and biases. Readings in Uncertain Reasoning, Edited by Glenn Shafer and Judea Pearl, Morgan Kaufmann Publishers, Inc. San Mateo, CA, pp. 32-39.

Van Der Doef, M. and Maes, S. 1999. The job demand-vontrol (-support) model and psychological well-being: a review of 20 years of empirical research. Work \& Stress, 13(2): 87-114.

Vredenburgh, A. G. 2002. Organizational safety: Which management practices are most effective in reducing employee injury rates? Journal of Safety Research, 33:259-276.

Williamson, A.M., Feyer, A.M., Cairns, D., and Biancotti, D. 1997. The development of a measure of safety climate: the role of safety perceptions and attitudes. Safety Science, 25 (1):15-27.

Wilson, W.F. 2004. Organizational Behaviour \& Work - A critical introduction, 2nd edition, Oxford University Press, New York.

WSIB. 2005a. Statistical supplement 2005. Workplace Safety Insurance Board, http://www.wsib.on.ca/wsib/wsibobj.nsf/LookupFiles/DownloadableFile2005StatisticalSu pplement/\$File/2278A_StatSup.pdf

WSIB. 2005b. Young worker statistics 2005. Workplace Safety Insurance Board, http://www.wsib.on.ca/wsib/wsibobj.nsf/LookupFiles/DownloadableFileYoungWorkerStat s2005/\$File/YoungWorkerStats2005.pdf

Zohar, D. 1980. Safety climate in industrial organizations: theoretical and applied implications. Journal of Applied Psychology, 65:96-102 